\title{
Growth and \\ Structural Change
}




\section{ECONOMICS TODAY}

Edited by Andrew Leake

The Economics Today series surveys contemporary headline topics in applied economics. Each book in the series is written by an expert in the field in a style that is fluently readable. It serves the student of introductory economic principles while also making the subject accessible to a more general reader. The series embraces the problem-solving skills of the new generation of students and stresses the importance of real-world issues and the significance of economic ideas.

\section{Published}

Andrew Leake: The Economic Question

Jean-Louis Barsoux and Peter Lawrence: The Challenge of British

\section{Management}

Andy Beharell: Unemployment and Job Creation

Frank Burchill: Labour Relations

Mark Cook and Nigel M. Healey: Growth and Structural Change

Kenneth Durham: The New City

S.F. Goodman: The European Community (2nd edition)

Kent Matthews: Macroeconomics and the Market

Charles Smith: Economic Development, Growth and Welfare

Jenny Wales: Investigating Social Issues

John Wigley and Carol Lipman: The Enterprise Economy

Margaret Wilkinson: Taxation

\section{Forthcoming}

Ian Hodge: Environmental Economics

John Wigley: The Rebirth of Russia

\section{Series Standing Order}

If you would like to receive future titles in this series as they are published, you can make use of our standing order facility. To place a standing order please contact your bookseller or, in case of difficulty, write to us at the address below with your name and address and the name of the series. Please state with which title you wish to begin your standing order. (If you live outside the United Kingdom we may not have the rights for your area, in which case we will forward your order to the publisher concerned.)

Standing Order Service, Macmillan Distribution Ltd, Houndmills, Basingstoke, Hampshire, RG21 2XS, England. 


\section{GROWTH AND STRUCTURAL CHANGE}

Mark Cook and Nigel M. Healey 
(C) Mark Cook and Nigel M. Healey 1995

All rights reserved. No reproduction, copy or transmission of this publication may be made without written permission.

No paragraph of this publication may be reproduced, copied or transmitted save with written permission or in accordance with the provisions of the Copyright, Designs and Patents Act 1988 , or under the terms of any licence permitting limited copying issued by the Copyright Licensing Agency, 90 Tottenham Court Road, London WIP 9HE.

Any person who does any unauthorised act in relation to this publication may be liable to criminal prosecution and civil claims for damages.

First published 1995 by

MACMILLAN PRESS LTD

Houndmills, Basingstoke, Hampshire RG21 2XS

and London

Companies and representatives

throughout the world

ISBN 978-0-333-56969-6 ISBN 978-1-349-12831-0 (eBook)

DOI 10.1007/978-1-349-12831-0

A catalogue record for this book is available from the British Library.

$\begin{array}{rrrrrrrrrr}10 & 9 & 8 & 7 & 6 & 5 & 4 & 3 & 2 & 1\end{array}$

$\begin{array}{llllllllll}04 & 03 & 02 & 01 & 00 & 99 & 98 & 97 & 96 & 95\end{array}$




\section{Contents}

List of Tables and Figures ix

1 Britain's Economic Growth Record 1

Economic Growth Defined 2

Britain's Economic Record 4

Explanations of Britain's Growth Record 8

Fiscal Policy 10

The Balance of Payments Constraint 11

Productivity Growth and the Structure of Employment 11

Supply-side Problems 12

The Thatcher Miracle? 12

The UK - the First Post-industrial Nation? 16

2 Growth and Structural Change in the British Economy 18

An Overview of Structural Change 18

Structural Change in the UK 21

North Sea Oil and its Impact on the UK Economy 30

The Stages of Growth Argument 34

Low Wage Competition 35

The Role of Multinationals 36

Crowding-out Revisited 37

Do Structural Changes Matter? 39 
3 Does Deindustrialisation Matter? 40

Definitions of Deindustrialisation $\mathbf{4 0}$

Bacon and Eltis's theory of Deindustrialisation 42

The OECD Definitions 42

Positive and Negative Impacts of

Deindustrialisation 48

The Regional Dimension of Deindustrialisation 49

Growth and the Manufacturing Sector 53

Balance of Payments Constrained Growth 55

Manufacturing's Future Return? 57

\section{Does Slow Growth Matter? 59}

The Benefits of Growth 59

Growth and the External Constraint 60

The Trading Patterns and Commodity Composition of the UK's Visible Trade 63

The Trade in Manufactures 63

Factors Responsible for the Change in Export and Import Performance 67

Non-price Competitiveness 69

Why the Need for a Manufacturing Sector? 70

Britain as a Low-wage, Low-productivity Economy 72

The Costs of Growth 75

The Limits to Growth 77

The Social Limits to Growth $\quad 78$

Can Britain Escape Slow Growth? 79

The UK's Attempts to Stimulate Growth 81

\section{Explaining Economic Growth 83}

The Aggregate Production Function 84

Total Factor Productivity 87

Economic Growth in the Aggregate Supply and

Demand Model 88

The Role of the Labour Market 91

The Short-run Aggregate Supply Schedule 91

The Long-run Aggregate Supply Schedule 95

Economic Growth and Long-run Aggregate

Supply 95 
Underlying Factors and Stimuli for Growth 98 Appendix 1: Economic Growth and the Business Cycle 99

Appendix 2: The Aggregate Production Function 103

6 Keynesian Prescriptions for Economic Growth 106

The $45^{\circ}$ Line Model 106

The Implications of the $45^{\circ}$ Line Model for Economic Growth 108

Market Failure and Externalities 111

Information and Economic Co-ordination 114

The Keynesian Prescription for Economic Growth 116 An Assessment of Keynesian Growth policies 121

7 New Classical Prescriptions for Economic Growth 123

Keynesian versus the new Classical Economics 123

The rationale of new Classical Growth Policies 124

Privatisation 125

The Deregulation of Goods and Financial Markets 128

Tax and Social Security Reforms 129

Labour Market Reform 131

Government Spending, Budget Deficits and Crowding Out 131

Synthesising the New Classical Debate 134

8 Capital Accumulation and Technological Progress 136

Britain's Record on Capital Investment 136

Research and Development 138

The Decision to Invest 139

The Role of Taxation and Subsidies 141

The Importance of Risk 142

Policies to Promote Investment 144

Investment and the Capital Market 151

Getting the Investment Climate Right 152 
9 Labour Market Flexibility and Human Capital 154

Aggregate Supply and the Labour Market 154 Trade Unions, Structural Change and Economic Growth 156

Other Obstacles to Labour Market Flexibility 157 Trade Union Legislation 158

The Effect of Taxes and Social Security on Labour Supply 162

Training and Education: the Key to Higher Productivity 168

Quality and Flexibility in the Labour Market 171

10 The Role of the European Union 173

State Aids to Industry 173

Mergers 175

Regional Policy 176

Social Policies 177

Increased Competition from Newly Industrialised Countries 178

Multinationals and Foreign Direct Investment 180

Employment and Trade Effects 183

Technology Transfer 184

The UK's Educated Labour Force 186

The Exhaustion of North Sea Oil 187

Growth Policies for the Twenty-first Century 189

Can the UK Achieve a Permanently High Growth Rate? 192

Index 195 


\section{List of Tables and Figures}

Tables

1.1 Growth Rates of Real Output per Worker Employed (\% per annum) 5

1.2 Manufacturing Productivity Growth - Annual per cent Change in Real Value Added per Person Employed 6

1.3 Real GDP per Hour Worked: Comparisons with the UK in Selected Years 7

1.4 Productivity in the Business Sector (Percentage Changes at Annual Rates) 9

1.5 Performance Indicators (Output per Worker, \% p.a.) 13

2.1 Index Numbers of Output at Constant Factor Cost, $(1980=100) \quad 22$

2.2 Percentage Shares of GDP at Factor Cost 24

2.3a World Trade Shares and Deindustrialisation (\%) 26

$2.3 \mathrm{~b}$ Deployment of the Labour Force (\%) 26

2.4 The Shift in Employment (GB thousands) 28

2.5 Components of the UK Current Account ( $\mathrm{fm}$ ) 31

2.6 Net External Assets of Selected Countries (\$bn) 33

2.7 The Long-run Relationship of the Marketed and Non-marketed Sectors (\% of Marketed Output) 38

3.1 Employees in Employment, by Industry (UK, 000) 43

3.2 Changes in the Labour Force - Selected Countries (\%) 44

3.3 Growth of Financial Services (GB) 45

3.4 Share of Manufacturing in GDP 46

3.5 World Trade Shares and Deindustrialisation (\%) 47

3.6 Uneven Geography of Economic Restructuring, 1971-9 and 1979-88 52 


\section{$\mathrm{x} \quad$ List of Tables and Figures}

4.1 The UK's Balance of Trade 62

4.2 Area Composition of UK Visible Exports $(X)$ and Imports $(M)$ (\% totals) 64

4.3 Commodity Composition of UK Visible Exports $(X)$ and Imports $(M)$ (\% totals) 65

4.4 Share of World Trade in Manufactures (\%) 66

4.5 Import Penetration in Manufactures for the UK (\%) 67

4.6 Productivity Growth in the Business Sector of OECD Countries (\% per year) 72

4.7 Hourly Wage Costs including Wage and Non-wage Costs $(\$, 1993) \quad 74$

$5.1 \quad$ Average Annual Growth Rates, 1870-1992 83

5.2 The Aggregate Production Function 85

5.3 Estimated Output Elasticities for Selected Industries 85

5.4 Annual Average Growth of Productive Capital Stock (\%) 86

5.5 Annual Average Growth of Labour Input (\%, 1900-87) 86

5.6 The Solow Decomposition Average Annual Growth Rates, 1900-87 88

5.7 Total Factor Productivity Annual Average Growth Rates (\%) 88

5.8 Economic Growth in a Stylised Business Cycle 104

6.1 Variability of Domestic Demand and Output, 1975-91 (at constant prices) 110

6.2 Variability of the British Economy, 1975-91 111

7.1 Major British Privatisations 126

7.2 The Role of the State in Direct Production 127

7.3 Estimates of the Size of the Black Economy (\% of GDP) 129

7.4 Taxes as a per cent of GDP, $1991 \quad 130$

7.5 Taxes on Labour $(\%, 1988) \quad 130$

7.6 The Multiplier and Crowding Out 132

7.7 Budget Deficit Targets and Outturns 135

8.1 Investment and Capital Accumulation in Britain by Sector 138

8.2 R\&D Expenditure (\% of GDP) 138

8.3 R\&D Expenditure and Patent Registrations (1989) 139

8.4 Real Interest Rates 146

8.5 Comparative Inflation Records (1979-92) 147

8.6 Average State Subsidies to Industry (\% of GDP) 148

8.7 The Prisoners' Dilemma 148

8.8 Main Tax Changes Affecting Companies Since $1979 \quad 150$

8.9 Corporate Tax Rates on Profit (\%) 150

8.10 Quoted Companies and Takeovers, 1990152

9.1 The Natural Rate of Unemployment (\%) 157

9.2 Trade Union Density 161 
9.3 Strike Activity in Britain 161

9.4 International Comparisons of Human Capital Acquisition 169

9.5 Apprentices in British Manufacturing Industries 170

9.6 Firms Constrained by Skill Shortages (\%) $\quad 170$

10.1 Subsidies as a Percentage of GDP 174

10.2 World FDI Outward Investment Flows (\%) 180

10.3 Largest Non-financial Multinationals 1990, Ranked by Foreign Assets (\$) 181

10.4 Net Foreign Investment Flows of the UK ( $£$ million) 182

10.5 International Comparisons of External Assets 188

\section{Figures}

1.1 Production Possibilities and Growth 3

1.2 Productive possibilities Curve 4

2.1 Employment Growth in Financial Services (\% per year, 1979-90) 29

2.2 The Stages of Economic Growth 35

3.1 Positive and Negative Deindustrialisation 49

3.2 Visible Balance of Commodity Groups, 1980 and 198850

3.3 The Balance of Payments Constrained Growth Rate 56

4.1 Alternative Growth Paths 76

5.1 Aggregate Demand, Aggregate Supply Model 89

5.2 The Aggregate Production Function 90

5.3 Equilibrium in the labour Market 92

5.4 Labour Market Equilibrium and Money Illusion 93

5.5 The Aggregate Supply Curve in the Short-run 94

5.6 The Aggregate Supply Curve in the Long-run 96

5.7 The Impact of Economic Growth on Output, Employment and the Wage Rate 97

5.8 Equilibrium Growth in a Dynamic Aggregate Demand, Aggregate Supply Model 100

5.9 The Business Cycle and its Impact on Growth 102

6.1 Keynesian Expenditure/Income/Output Model 107

6.2 Aggregate Demand, Aggregate Supply in Keynesian Model 109

6.3 The Case of Negative Externalities 112

6.4 The Case of Positive Externalities 113

6.5 The Advantages of Publicly Owned Monopolies 118

6.6 Price/Output Equilibrium under a Natural Monopoly 120

7.1a Equilibrium in the Money Market 133

7.1b Interest Rates and Investment 133

8.2 Trade-off Between Risk and Expected Return 143

9.1a Shifts in the Long-run Aggregate Supply Curve 155

9.1b Improvements in the Quality/Productivity of Labour 155 


\section{xii List of Tables and Figures}

9.1c The Impact of an Increase in the Quantity of Labour 155

9.2 The Income/Leisure Trade-off 163

9.3 Reduction in Taxes and the Income/Leisure Choice 164

9.4 Alternative Income/Leisure Choice Decision after the Result of a Tax Change 166

9.5 Impact of Social Security Benefits on Income/Leisure Choices 167 